\title{
Using Shared Reports to Explore the Nature and Resolution of Critical Incidents between Higher Education Teachers and Students
}

\author{
Ernesto Panadero $^{1}$ and Carles Monereo ${ }^{2}$ \\ ${ }^{1}$ Faculty of Education, University of Oulu, Finland \\ ${ }^{2}$ Departamento de Psicología de la Educación de la Universitat Autònoma de \\ Barcelona, Spain.
}

\section{Finland \& Spain}

Correspondence: Ernesto Panadero. Department of Educational Sciences and Teacher Education, Learning and Educational Technology Research Unit (LET). PO BOX 2000, Fin-90014 University of Oulu (Finland).. Nombre de País. E-mail: ernesto.panadero@oulu.fi

(C) Education \& Psychology I+D+i and Ilustre Colegio Oficial de Psicología de Andalucía Oriental (Spain) 


\begin{abstract}
Introduction. A critical incident is an event that occurs in a delimitated place and time producing in the professional an emotional state -usually negative- and destabilizing his/her professional identity. Critical incidents have been used to study teachers' professional development and identity. This study aim is to better understand the effect of critical incidents in higher education.
\end{abstract}

Method. 11 university teachers and 88 of their students participated in this study. During one semester they filled out three different surveys weekly. During six weeks each teacher and her students reported the occurrence of critical incidents in the classroom using the first survey. After the six weeks, the survey answers were exchanged: the teachers could read the students' and vice versa. In the second survey the participants reported their reactions after reading the first survey answers. In the third survey students and teachers reported their reactions to the second survey exchange and, additionally, the teachers reflected on their pedagogical strategies.

Results. Teachers and students reported different events as critical incidents. Teachers reported challenges to their authority or lack of students' motivation. Students reported as critical incidents problem during collaborative activities, lack of understanding about tasks' goals and arguments among peers. Additionally teachers reported to have gained new insights about their pedagogical strategies and proposed changes in their teaching style and classroom activities.

Conclusions. The students' and teachers' divergent interpretation of events as critical incidents points out the importance of the role of the "educational agent". This is, teachers are usually in a more salient role as they are directing the classroom and, therefore, have different goals than the students. For this reason they experience critical incidents from different events challenging their role as teachers. The methodology of shared reports is appropriate to provoke reflection and changes on the teachers' pedagogical strategies.

Keywords: teacher professional identity, critical incidents, teacher training, shared reports, higher education. 


\section{El Uso de Informes Compartidos para Explorar la Naturaleza y la Resolución de Incidentes Críticos entre Profesores y Alumnos de Enseñanza Superior}

\section{Resumen}

Introducción. Un incidente crítico ocurre en un lugar y tiempo determinado generando en el profesional un estado emocional -habitualmente negativo- y desestabilizando su identidad profesional. Los incidentes críticos se estudian en relación al desarrollo profesional e identitario de los profesores. El objeto de este estudio es entender mejor el efecto de estos incidentes críticos en la enseñanza en educación superior.

Método. 11 profesoras universitarias y 88 de sus alumnos participaron en este estudio. Durante un semestre contestaron a tres cuestionarios de forma semanal. En el primer cuestionario cada profesora y sus alumnos informaron sobre sus experiencias de incidentes críticos en clase. Después de seis semanas intercambiamos las respuestas de alumnos y profesoras. En el segundo cuestionario los participantes expresaron sus reacciones tras leer las respuestas al primer cuestionario. En el tercer cuestionario los estudiantes y las profesoras informaron de sus reacciones al segundo cuestionario y, adicionalmente, las profesoras reflexionaron sobre los cambios en sus estrategias pedagógicas promovidas por el intercambio de información.

Resultados. Las profesoras y sus estudiantes identificaron diferentes eventos como incidentes críticos. Las profesores identificaron situaciones en las que su autoridad se puso evidencia o la falta de motivación de algunos alumnos. Los estudiantes identificaron situaciones en las que tuvieron problemas para trabajar en grupo, no entendían los objetivos de una actividad o había un enfrentamiento entre los compañeros de clase. Adicionalmente las profesoras informaron que habían obtenido una mayor comprensión sobre su forma de enseñar a través del uso de los informes compartidos y propusieron cambios en sus estrategias docentes.

Conclusión. La interpretación divergente de los alumnos y las profesoras sobre lo que constituye un incidente crítico señala la importancia del papel el actor educativo. Esto es, los profesores están habitualmente en un papel más destacado en el aula pues llevan el peso de las sesiones. Además hay diferencias entre los objetivos de los profesores y los alumnos. Por este motivo hay diferencias entre cómo profesores y alumnos interpretan y vivencian los incidentes críticos. La metodología de informes compartidos es apropiada para generar reflexiones y cambios en las estrategias pedagógicas de los profesores.

Palabras Clave: identidad profesional docente, incidentes críticos, formación profesorado, informes compartidos, educación superior. 


\section{Introduction}

Beginning of a session in a secondary education classroom. The teacher asks some questions about a text that students should have read for that session. Students remain silence. Then the teacher asks if anyone has read the text. Silence again. The tension of the situation increases. Finally the teacher says aggressively: "Alright, I will extract one point from your final course score". Before the protest increases the teacher leaves the room. (This situation has been taken from a real experience found in previous research conducted by the authors).

These types of events are called critical incident. According to Everly \& Mitchell (1999) a critical incident is an event that occurs in a delimitated place and time producing in the professional a negative emotional state and destabilizing his/her professional identity. To recover from this type of critical incident the professional will frequently need more than using remedy strategies but he/she will need to create a new version of himself/herself, a new identity (Lea \& Stierer, 2011). For this same reason, critical incidents shake the professional identity foundations having a profound impact in the teacher's cognitive and emotional state. However, it is important to point out that critical incidents do not only have negative outcomes but teachers can also extract positive reflections from them and change their praxis.

One of the key aspects regarding critical incidents is that they are subjective and open to interpretations: each professional determinates what represents a critical incident (Day, Kington, Stobart \& Sammons, 2006). Therefore, two similar events could have complete different interpretations by two professionals even from the same field (Akkerman \& Meijer, 2011; Monereo \& Badia, 2011).

One of the fields in which professional identity and critical incidents have become a major area of research is teacher training (Akkerman \& Meijer, 2011; Beijaard, Meijer, \& Verloop, 2004). It has been long known that teachers' instructional approach, which depends on their identity, has a crucial and direct impact on their students' learning (Alonso-Tapia \& Fernandez, 2009; Good, 1987). To a major extent the classroom climate depends in the teachers' ability to conduct the sessions and how they handle the different events that happen in their classrooms. Precisely because of that, teacher training programs should aim to develop competent teachers that are able to interpret different situations and educational contexts, put- 
ting into practice the improvements proposed in the educational reforms (Jeffrey \& Woods, 1996; Lasky, 2005; Van Veen \& Sleegers, 2009).

For this reason there is an increasing number of studies being conducted in which the main aim is to analyze how we can train strategic and competent teachers that are able to cope with different and challenging situations (Hung, Der-Thanq, 2007; Keltchtermans et al., 2007). Among this increasing research on teacher training, as mentioned before, is the study of how the development of professional identity impacts the teacher training and practice (Beijaard et al., 2004; Day, Kington, Stobart, \& Sammons, 2006; McAlpine, Weston, Berthiaume, \& Fairbank-Roch, 2006).

\section{Teacher identity: definition}

Teacher professional identity can be defined as the group of internal representations that teachers holds about their own teaching and role as docents which are stable across time and content delimitated (Beijaard et al., 2004; Monereo, Panadero \& Scartezini, 2012). This concept has a long tradition in psychology especially in interventions in clinical and social psychology (Monereo \& Pozo, 2011). However, in recent years with the growth of the studies about conceptions, strategies and emotions related to teaching and learning, the concept of identity has been explored from scholars coming from the educational psychology (e.g. Lea \& Stierer, 2011). The study of teachers' identities is an excellent analysis concept that unifies teaching conceptions, instructional strategies and emotions related to the classroom. And, at the same time gives the ground to analyze dynamic concepts related to specific contexts and interactions.

However, the concept of identity is one open to multiple interpretations and it is important to clearly state how it conceptualized. In the field of educational psychology the teacher identity has been considered as one entity: one professional and one way of acting. However that vision is changing (Monereo \& Badia, 2011). Several studies have explored how one teacher does not act the same in different subjects, classroom groups and educational levels, defying the concept of identity as unique, permanent and stable. Teachers use different instructional strategies depending on the context and the audience (Lea \& Stierer, 2011). Far from being a negative feature of teachers' identity, when these differences are consciously planned, students can benefit from it. 
In the present study is grounded in the theoretical identity framework developed by Monereo and Badia (2011). In this framework teachers' identity is based and developed around three categories. In each of these categories the teachers are self-symbolized being able to interpret and show different aspects of their identity. These three categories are:

a) Professional role conceptions: Through these conceptions teachers represent themselves in terms of their relationship with their working context. For example when they represent themselves as educators, professionals on their subject, researchers, etc. These conceptions are highly influenced by the educational level in which the teachers work (e.g. a primary teacher will hold different conceptions that a higher education teacher) (Day et al., 2006).

b) Learning \& teaching conceptions: they are highly dependable on the subject and the area of teaching (Muis, 2007). They are the explicit and implicit knowledge that is part of the teachers conceptions about the meaning and final aim of what they are teaching and their subject (Pozo, 2006). Therefore these conceptions are crucial in how the teachers conceptualize what represents the best way to teach their subject. This line of research has been very active and there is a wide range of studies exploring how these teaching conceptions affect students' learning and their use of learning strategies (Lotter; Harwood \& Bonner, 2007; Muis \& Franco, 2009; Van Petegem \& Donche, 2006).

c) Conceptions about emotions related to teaching: in the classroom there are events that produce emotions that can trigger critical incidents (Shapira-Lishchinsky, 2011). How teachers conceptualize and interpret these emotions influences their perception as positive, neutral or negative emotions.

According to Monereo y Badia (2011) these three categories of conceptions are the ones that build up the teacher identity influencing one another. At the same time the identity influences how teachers act: how they interact with the students, what instructional strategies they use, how they work with their colleagues, etc. It is important to point out again that, though the identity is usually coherent from the teachers' own point of view, they might show different versions of themselves depending on the context. Therefore it is important that teachers reflect about how their identity influences their teaching and how they interact in the educational settings. Unfortunately this is usually an area that is not emphasized in the training programs and such reflection depends on the teachers' own experiences. 


\section{Teacher training programs and critical incidents}

As teachers do not usually get training on these conceptions and how they might impact their professional role the development of the professional identity will depend on their personal features. It is a fact that teachers' identity develop along with their teaching practice (Akkerman \& Meijer, 2011; Day et al., 2006; Monereo et al., 2012), but having previous training and reflection would be crucial to react to the critical incidents that they will experience along their careers. The more experience and reflection on how to handle critical events the more adaptive and productive their reactions and interpretations of these events will be. Because, regardless of the fact that teachers might or might not receive training, they will in any case face this type of events that have an influence on how their professional identity. Actually, it has been found that experienced teachers are able to clearly identify those critical events that were breaking points on their careers reporting that they would have liked to have better skills to face those events (Day et al., 2006). Yet, they recognized that they "survived" to those experiences but through painful process that could have been easier if they would have had the necessary skills (Shapira-Lishchinsky, 2011; Sutton \& Wheatley, 2003; Wudy \& Jerusalem, 2011).

As with other implicit learning situations, teachers find their own solutions for critical events. However sometimes teachers' reactions are not planned but rather based on emotional automatic responses that might create additional problems (Monereo, 2010). This is even more important in educational contexts as teachers are in front of an audience making more challenging to give an adequate response. It is then clear that teachers could benefit to a great extent from receiving training on how to face these critical incidents and find the best solutions. In the mid-90s Tripp (1993) arrived to this conclusion and he started a research line on critical incidents trying to identify and explore these events and how to handle them. Since them the field has grown exponentially (e.g. Metcalfe \& Matharu, 1995; Shapira-Lishchinsky, 2011).

\section{Critical incidents in teacher training programs and the use of shared reports}

The potential of using critical incidents embedded in teacher programs is that they connect with teachers' emotions. Connecting with emotions is important when interventions look for changes in knowledge or structured cognition as emotions enhance the motivation for the change (Pintrich, Marx, \& Boyle, 1993; Sutton \& Wheatley, 2003). Usually, even when 
teachers have not suffered the same critical incidents that are presented in the training programs they still relate to similar events that have triggered similar emotions. Teachers actually feel that getting training about critical incidents is more important than receiving theoretical lectures that are not so connected with what really happens in classroom (Monereo, 2010).

A critical event that has been properly resolved, even if it triggered negative emotions in the initial phase, helps to re-conceptualize and strength the teachers' identity adding more instruccional and emotional strategies to their repertoire (Monereo et al., 2012). On the contrary, a critical incident that has not been resolved can lead to a weakness on the teacher's identity and to a destabilization that would affect the teacher's security fearing that the same could happen again (Shapira-Lishchinsky, 2011; Wudy \& Jerusalem, 2011). For these reasons it is crucial that teacher programs, whether they are for pre-service teachers or experienced teachers, covered these issues offering training and support (Beijaard et al., 2004; Monereo et al., 2009).

One approach to reflect about critical events has been the use of reports (Monereo et al., 2012): teachers reflecting about the nature of their critical. As it is well known the use of self-report as a technique to reflect about different events is a powerful strategy to reappraise negative events and develop skills to cope with them the coming times (Kanfer, 1977; Kanfer \& Goldstein, 1991). There is also another important and positive aspect of using written reports: they can be shared. An innovative approach is using these reports in ways that teachers and their students could benefit from sharing them. As critical incidents experiences usually happen in classroom the students have a crucial role in how the teacher solve and interpret the event. Therefore including the students in the analysis of the critical incidents could have a number of positive outcomes: teacher reinterpretation of the event, offering solutions to those situations, emotional support for the teacher, etc. In sum, these reports become part of the intervention. Monereo, Panadero and Scartezini (2012) explored these ideas and methodology with promising results, building up on Weise (2011) research on the different levels of change that can be promoted through teachers training interventions. According to Weise (2011) interventions can have different impacts on teachers connecting to the level of appropriation of the new ideas. These levels are organized from the one in which the intervention would produce the more superficial change to the one with deeper implications. 
Table 1. Levels of change on professional identity after a critical incident

\begin{tabular}{|c|c|c|}
\hline Level & Variable & Type of change \\
\hline 1 & Critical incident occurrence. & $\begin{array}{l}\text { Awareness about the critical incident and its } \\
\text { relevance. }\end{array}$ \\
\hline 2 & $\begin{array}{l}\text { Reflection about the critical } \\
\text { incident impact. }\end{array}$ & Change in the teacher's discourse. \\
\hline 3 & $\begin{array}{l}\text { New practices -pedagogical } \\
\text { strategies-. }\end{array}$ & $\begin{array}{l}\text { Change in the usual classroom teaching } \\
\text { strategies. }\end{array}$ \\
\hline 4 & $\begin{array}{l}\text { Learning from the critical inci- } \\
\text { dent. }\end{array}$ & $\begin{array}{l}\text { Awareness of the change in the conceptions } \\
\text { and the teaching strategies. }\end{array}$ \\
\hline 5 & Learning continuity over time. & $\begin{array}{l}\text { Changes are permanent in the conceptions } \\
\text { and teaching strategies. }\end{array}$ \\
\hline
\end{tabular}

In their pilot study, Monereo et al. (2012) concluded that the intervention using shared reports during a semester and exchanging them among the teacher and his students promoted a $3^{\text {rd }}$ level change on the participant teacher. They could not conclude whether changes in $4^{\text {th }}$ and $5^{\text {th }}$ level happened as their study was not prolonged over time to test that hypothesis. In the present study however this would be explored amplifying the data collection. Another conclusion of that study is that the use of shared reports needed further exploration with a bigger sample including different teachers and their corresponding students.

\section{Aim and research questions}

The main aim of this study is to explore how the process of sharing reports between teachers and their students might impact their perceptions on critical incidents over one semester. There are four research questions:

a) Do teachers and students report the same type critical incidents?

b) What are the main conflicting areas that produce critical incidents?

c) Does the shared report methodology generate changes on the teachers' instructional strategies? What level of teacher change was achieved, if any?

d) Does sharing such report create critical incidents itself?

With these research goals in mind we proceed to explore and validate the use of shared reports on critical incidents among university teachers and their students. 


\section{Method}

\section{Participants}

Initially 15 higher education teachers from four Spanish speaking public universities were willing to participate, after an official call to four Educational Psychology departments in four different universities (two in Spain and two in Mexico). These departments were contacted because the researchers have colleagues that could be interested in implementing this research. The teachers that accepted to participate did so voluntarily with the goal of reflecting about their own teaching praxis. Then the students of those 15 teachers were contacted trying to get a significant number of them, at least 5 students per each participant teacher. Unfortunately, there were insufficient students for 4 of the teachers. Therefore 11 university teachers and an average of 8 students for each of them compounded the final sample.

The range of teachers' experience was five to eighteen years. Therefore all of them can be considered experienced teachers. Seven of the teachers chose to participate with a classroom group of undergraduates and the other five with graduates' students. All teachers were females.

The students were pre-service teachers (45\%) and psychology students (55\%), undergraduates (62\%) and graduates (38\%), and majority of females (71\%). The students were guaranteed confidentiality assigning them a personal code once they filled in the first questionnaire. Also, it was guaranteed that if they decided not to continue with the study their teachers wouldn't be informed. To maintain the participation during the semester a free subscription to an academic journal was offered to the students that completed the study.

\section{Instruments}

Classroom conceptions \& critical incidents survey: Compounded of 7 questions in the student's version and 10 in the teacher's. In this survey the participants report the development of the course during the semester and also the occurrence of critical incidents. The survey has three categories of questions: (a) Development of the course along the semester and satisfaction with the classroom group, (b) Critical incidents, and (c) Suggestions for changes to improve the course. The teacher's version has three additional questions in the critical incident category. As this is the main focus of this study next we will reproduce those questions: (1) Has anything uncomfortable happened in the last session?, (2) What exactly happened?, (3) 
What did you think, feel and how did you react?, (4) How was it solved?, (5) What is the origin of this event?, (6) If facing similar situations in the future, how do you think you would feel? How would you react? What decisions would you take? Students were asked the same questions except for the third, fifth and sixth.

Reactions after reading the shared reports survey: this instrument measures the reactions of the teacher and students after reading what the other part (e.g. teacher read students) wrote on their Classroom conceptions \& critical incidents surveys. It is compounded of three questions on both versions -teacher and students-: (a) Reactions after reading the shared reports, (b) Discussion points, and (c) Emotional reactions.

Change perception survey: this instrument explores the teacher and students' reactions after reading the commentaries of the other part on the Reactions after reading the shared reports survey. Compounded of 4 questions on both versions: (a) Reactions after reading the reactions of the other, (b) Critical events previous experience, (c) Changes on teaching or learning strategies, (d) Utility of the shared reports.

\section{Procedure}

First, teachers from four universities working in education and psychology faculties were contacted for their participation. Those who volunteered were given an explanatory text about the study that they forwarded to their students. From that point only the researchers contacted the participant students. When students replied back they were included in the database and received more information about the study procedure. At this phase of the study 4 teachers could not continue due to their low number of students interested in participating.

Those students and teachers that continued received a link to the Classroom conceptions \& critical incidents surveys to fill it out online one week after their first class. Then, every week the survey was resubmitted up to six times. One week after they filled out the last time the first survey the researchers compiled and organized the database. They sent to the teacher the ones by the students and vice versa, asking at the same time to fill out the Reactions after reading the shared reports survey. Two weeks later the researchers compiled and organized the new data and, again, sent to the teacher the students' replies and vice versa. Also at the same time they were asked to fill out online the Change perception survey. Finally 
all the participants received an annual subscription to an academic journal of their liking on the education and psychology areas.

\section{Method of analysis}

The researchers prepared all the data and give it to two researchers not related to this study who conducted the content analyses. With regards to the questions about the development of the course and satisfaction with the group the two researchers were asked to read all the answers and point out the most salient features. Regarding the critical incidents data the two independent researchers plus one of this study researchers analyzed all the critical incidents reported. First they categorized the type of critical incidents according to a previously established taxonomy. Second, they analyzed the answer of each teacher's students to explore if they reported the same incidents. Third, the researchers analyzed the answer of the teachers regarding their perceived level of change and their reflections about the critical events. Fourth, the researchers reviewed the reactions after sharing the reports to check for critical events that might have been triggered by means of sharing this material.

The three researchers agreed in all the different reviews of the data except for one critical incident categorization that was decided after re-analyzing that specific case. It is important to point out that all the analysis conducted were based on very specific questions. Therefore the answers given by the teachers and students did not have a big range of interpretation. As an extreme example, the questions whether there has been critical incidents was usually replied by a yes or not. For the answers where there was some degree of interpretation (a total of 14 questions) the two external researchers and one of the authors calculated interjudges agreement. The Cohen's kappa values of inter-rater agreement range from 0.83 to 0.91 . These high values are due to the high structure taxonomy previously established through negotiation and the limit range in the participants' answers.

\section{Results}

Data coming from the Classroom conceptions \& critical incidents survey points out that students and teachers were in general satisfied with the development of the course during the semester. The students reported being satisfied with the teacher and the session organization. This points out that, overall, the classroom climate were positive which might have modulated the results of this study. Now, the results related to our research questions will be presented. 
Do teachers and students report the same critical incidents?

Teachers reported a total of five critical incidents during the first phase of the research -the six weeks answering the Classroom conceptions \& critical incidents survey-. Students reported a total of twenty-three critical incidents in the same six weeks. However there is only one case in which a student is reporting the same critical incident as the teacher but in different weeks. In sum students and teachers do not shared what they consider to be critical incidents as their reports do not coincide. What could be reason for these divergent conceptions about what constituted a critical incident? The next section explores it.

What are the main conflicting areas that create critical incidents in teachers and students?

The previous research question results emphasize the important to explore what are the main areas that create critical incidents in the classrooms. To analyze this data we used the taxonomy shown in Table 2.

Table 2. Critical incidents topics

\begin{tabular}{lcc}
\hline \multicolumn{1}{c}{ Critical event } & Teacher & Students \\
\hline Authority & 4 & 1 \\
\hline Lack of motivation & 1 & 0 \\
\hline Discussions students and groups & 0 & 14 \\
\hline Understanding learning goals & 0 & 6 \\
\hline Session organization & 0 & 2 \\
\hline
\end{tabular}

Authority: in three occasions teachers -twice the same one- felt that their expertize was being challenged by a particular student. Additionally a teacher was upset once because three students left before the end of the session. One student reported the same critical event but one week earlier, so that was happening in a regular basis but the teacher only reported once.

Lack of motivation: a teacher reported one critical incident regarding one student lack of interest on her course.

Discussions between students and within working groups: the students reported critical incidents when the peers argued (e.g. opening the windows in the room) or when group work was unsuccessful for several reasons (e.g. lack of collaboration between group members).

Understanding learning goals: students reported six critical incidents regarding lack of understanding about the classroom activities goals. 
Sessions organization: two students reported critical incidents related to the way the teacher organized the semester sessions.

From this data it can be extracted that students and teachers do not share their perceptions about what constitutes a critical incident. Teachers experienced critical events when their authority was as risk, especially if their expert voice was being scrutinized. At this point, it is important to remind that teachers and students were in general satisfied with the classroom climate. On the other hand, students experienced critical events when their peers argued among themselves or when their working groups did not achieve the learning goals. The second cause that was reported by the students was when they did not understand what the goals for a task were. In sum, these results point out why teachers and students did not perceive the same critical incidents: each of them emphasize different events as causing critical incidents.

Does the shared report methodology generate changes on the teachers' instructional strategies? What level of change was achieved if any?

This research question was explored with the data from the Reactions after reading the shared reports survey. One of the teachers did not answer this survey. Nine out the 10 teachers reported their intention of making changes on their instructional strategies. These changes are summarized in Table 3.

Table 3. Changes on teachers' instructional techniques after sharing reports

\begin{tabular}{ccccc}
\hline Teacher & $\begin{array}{c}\text { Changes pro- } \\
\text { gram }\end{array}$ & $\begin{array}{c}\text { Collaborative work \& } \\
\text { structure }\end{array}$ & $\begin{array}{c}\text { Better diagnosis stu- } \\
\text { dents levels }\end{array}$ & $\begin{array}{c}\text { More discipline } \\
\text { \& demand }\end{array}$ \\
\hline 1 & $\mathrm{X}$ & $\mathrm{X}$ & & \\
\hline 2 & $\mathrm{X}$ & & & $\mathrm{X}$ \\
\hline 3 & & $\mathrm{X}$ & $\mathrm{X}$ & \\
\hline 4 & $\mathrm{X}$ & & & \\
\hline 5 & & & & \\
\hline 6 & $\mathrm{X}$ & & & \\
\hline 7 & $\mathrm{X}$ & $\mathrm{X}$ & & \\
\hline 8 & $\mathrm{X}$ & $\mathrm{X}$ & & \\
\hline 9 & $\mathrm{X}$ & & & \\
\hline
\end{tabular}

As can be seen teachers aimed at changing aspects mainly from the course program (e.g. including more activities, inviting more experts for lectures), offering more collaborative work to the student and improving the structure in which groups work. If we go back to the 
aspects that triggered more critical incidents on the students -Discussions between students and groups \& Understanding learning goals- it is easy to notice that teachers have taken notice of the pedagogical aspects that worried their students the most. Therefore, sharing reports with the students made our participant teachers aware of aspects that could improve and they proposed changes.

With regards to the level of change achieved by our intervention it is important to firstly point out to the main limitation. We only had data coming from self-report and from one semester. Therefore our data is based on what the teachers are reporting that they change in the future but we did not check if this happened. For this reason we can only conclude that our teachers are reporting a third level change using new teaching techniques (Weise, 2011) but not any further as we would need to follow the teachers development in the coming courses and semesters.

Does sharing such report create critical incidents themselves?

The purpose of this research question was to explore if the shared reports methodology triggered critical incidents itself. If this was the case, it could be used as a methodology in teachers' training program to promote deeper levels of change. This is so as using shared reports teachers have access to their students' thoughts and feelings about their teaching, something that is not usual to have information about.

This question was explored through the data from the Reactions after reading the shared reports survey. One of the questions asked our participant teachers whether they experienced a critical incident by reading their students comments about their course and teaching style (Table 4). One of the teachers did not answer this survey.

Table 4. Critical incidents experienced by the teachers after reading students reports

\begin{tabular}{lc}
\hline \multicolumn{1}{c}{ Critical event } & Teacher $N$ \\
\hline No critical event & 5 \\
\hline Positive critical incident accessing to students' perceptions & 2 \\
\hline No critical event looking for internal coherence & 1 \\
\hline No critical event but worries regarding some opinions & 1 \\
\hline Yes, critical incident & 1 \\
\hline
\end{tabular}


As can be seen the majority of teachers did not experience critical incidents after reading the shared reports. Five teachers reported not having a critical incident while other two reported having positive critical incidents by accessing their students' reports. One teacher was only concerned whether or not she had been coherent reporting her own thoughts and feelings during the six weeks, but not about what her students have shared. Another teacher reported that she did not experience a critical incident but that she was somehow worried about some of her students' critiques and she would have liked to discuss these issues with them face to face. The last teacher experienced a critical incident while reading her students' report. This teacher is the same one that experienced two critical incidents during the six week first phase because of the authority issues. In sum, half of the teachers experienced some level of positive or negative state after reading their students' reports while the other half of the teachers did not have any reaction.

\section{Discussion}

In this study it was explored how the use of shared report written by different teachers and some of their students during six weeks might help in terms of detecting critical incidents, solving them and what pedagogical changes they might produce in the teachers. The aim for future interventions is to incorporate these conclusions to teachers' training programs to help these develop skills to manage critical incidents.

It is important to remind that our results were modulated by the positive classroom climate that our teachers and students reported. Our teachers and their courses were perceived as satisfactory which might have a positive impact in the number of critical incidents experienced by the students, in line with previous research that have shown that students' motivation and use of learning strategies increases when there is a positive classroom climate (Alonso-Tapia \& Fernández, 2009).

Our first research question explored if teachers and students shared their perceptions about critical incidents. This question is relevant because previous research has shown that critical incidents are mainly based on individual perceptions (Beijaard et al., 2004; Monereo \& Badia, 2011; Monereo et al., 2012). Therefore if students and teachers shared what constitutes a critical incident that would unify what aspects need to be address when intervening. From our results can be concluded that teachers and students experience different aspects to trigger critical incidents. The second research questions addressed which areas are the ones 
that produce critical incidents for teachers and students. Our data shows that teachers and students in classroom with positive climate do not experience critical incidents from the same events. This finding is directly related to the fact that students and teachers have different roles and perceptions about what happens in the classrooms. Here it is important to bring forward one hypothesis from Monereo et al. (2012): the role of the participant in a critical incident might be crucial.

According to Monereo et al. (2012), teachers usually have an active role throughout the majority of their sessions. Therefore if an event is related to them directly (e.g. challenge their authority) they will immediately experience a critical incident. When there is an even that involves a mild discussion between a teacher and a student only that one specific student tended to experience it as a critical event while the rest of peers in the classroom did not even report about it (Monereo et al., 2012). Therefore, the salient role of the teachers as the main actors makes them more exposed to experience critical incident they occur. In the other hand, the same can be said with regards to the students: they experience a critical incident when they have active roles (e.g. while making a presentation). This study results show that students reported critical incidents when problems arise in their working groups, when they did not understand the tasks goals or when two peers argued. Two main conclusions can be extracted. First, in classrooms with positive climates students and teachers do not perceive the same critical events and, second, the role that the individual has in that particular event directly influences experiencing a critical incident or not.

With regards to the third research question, does the shared report methodology helps teachers to reflect about their work, from our data it seems like the methodology has helped teachers to reflect. The majority of participant teachers reported taking instructional recommendations from the students seriously and implementing them in the future. Moreover, teachers focus these improvements in the same areas that students were worried about: changes in the program to make it more understandable and easy to follow, and regarding collaborative work and how the groups are organized. Therefore there is a clear gain in using shared reports methodologies went it comes to improve the teachers' pedagogical techniques: reading students comments about their courses is used by the teachers to improve their teaching. This is in line with previous research in which asking teachers to explain their thinking when teaching and planning increased their awareness and reflection on their pedagogical strategies (e.g. McAlpine et al., 2006). 
A second purpose of shared reports is using them in teacher training programs as reflection tools. That was our fourth and last research question: does sharing the reports generate critical incidents? And the answer is that they only partially promote critical incidents -3 out of the 10 teachers reported some type of concern regarding the shared reports-. Several aspects need to be bear in mind when interpreting these results. First, the participants in this study are experienced teachers and therefore they might already suffer critical incidents in the past that might serve to make this methodology less harmful or even more productive (Day et al., 2006). Second, two of the teachers approached this situation as a positive learning experience. This modulates their interpretations of the reports in positive ways that can still be used for reflection purposes in teacher training programs (Darby, 2008; Shapira-Lishchinsky, 2011). Third, there have not been major critical incidents in our sample most probably due to the general positive climate. Nonetheless, the experience could have been enhanced by the intervention of a mediator that would have moderate between teachers and students promoting deeper reflection about the critical incidents that occurred.

\section{Limitations}

There are a number of limitations in this study. First, our data is of exploratory nature, therefore not casual explanations can be extracted. Second, it is difficult to determinate if the students regarding their teachers could have been driven by social desirability, but due to the highly structured anonymous process this effect might have not been so salient. Third, with regards to the level of change achieved by our intervention we only had data coming from self-report and from one semester. Therefore our data is based on what the teachers are reporting that they will change in the future. There are no latter measures to check the actual occurrence of these changes.

\section{Future lines of research}

As the use of shared reports for critical incident purposes is a new field there are a number of future lines of research to explore. The first is to cross-validate the data with direct qualitative measures (e.g. classroom direct observation). Though the perception of the critical incidents is of subjective and inner nature -each individual has different ideas of what constitutes a critical incident-, an observer could explore in more detail the classroom interactions and how the teachers solve this type of events. 
Second, the potential of the shared reports methodology can be enhanced if a mediator works with the teachers and students. This would be especially relevant in situations when the perceptions of teachers and students generate critical incidents.

Third, it is needed to explore the shared reports methodology in contexts in which there are severe conflicts affecting the classroom climate. Up to now data has come from classroom where the positive climate has modulated the number and intensity of the critical events. The field needs to move to situations in which critical incidents happen more frequently. In such contexts the real potential of the shared incidents methodology to help resolve such conflicting issues could be explored.

Fourth, this research should be conducted in other countries to cross-check for cultural differences. It could be the case that teachers or students from different cultures might have different conceptions about what constitutes a critical incident.

In conclusion, the use of shared reports has potential to help teachers reflect about their own practice and how to improve it. Being able to access the students' conceptions about the teacher style can significantly promote changes on teachers' pedagogy. Therefore the use of shared reports could be a valuable methodology to be applied in teachers' training programs. Especially as this methodology can be easily implemented through ecological tools embedded in the classroom activities, allowing for a better reciprocal communication that generates feedback to create better learning environments.

\section{References}

Akkerman, S. F., \& Meijer, P C. (2011). A dialogical approach to conceptualizing teacher identity. Teaching and Teacher Education, 27(2), 308-319. doi: 10.1016/j.tate.2010.08.013

Alonso-Tapia, J., \& Fernandez, B. (2009). A model for analysing classroom motivational climate: Cross-cultural validity and educational implications. Infancia y Aprendizaje, 32(4), 598-612.

Beijaard, D., Meijer, P. C., \& Verloop, N. (2004). Reconsidering research on teachers' professional identity. Teaching and Teacher Education, 20(2), 107-128. doi: 10.1016/j.tate.2003.07.001 
Darby, A. (2008). Teachers' emotions in the reconstruction of professional self-understanding. Teaching and Teacher Education, 24(5), 1160-1172. doi: 10.1016/j.tate.2007.02.001

Day, C., Kington, A., Stobart, G., \& Sammons, P. (2006). The personal and professional selves of teachers: Stable and unstable identities. British Educational Research Journal, 32(4), 601-616. doi: 10.1080/01411920600775316

Everly, Jr.,G.S., \& Mitchell, J.T. (1999). Critical Incident Stress Management (CISM): A new era and standard of care in crisis intervention (2nd Ed.). Ellicott City, MD: Chevron.

Good, T. L. (1987). Two decades of research on teacher expectations: Findings and future directions. Journal of Teacher Education, 38(4), 32-47. doi: $10.1177 / 002248718703800406$

Hung, D., \& Victor Chen, D. T. (2007). Context-process authenticity in learning: Implications for identity enculturation and boundary crossing. Educational Technology Research and Development, 55(2), 147-167. doi: 10.1007/s11423-0069008-3

Jeffrey, B., \& Woods, P. (1996). Feeling deprofessionalised: The social construction of emotions during an OFSTED inspection. Cambridge Journal of Education, 26(3), 325-343. doi: 10.1080/0305764960260303

Kanfer, F. H. (1977). The many faces of self-control, or behavior modification changes its focus. In R. B. Stuart (Ed.), Behavioral self-management: Strategies, techniques, and outcomes (pp. 1-48). New York: Brunner/Mazel.

Kanfer, F. H., \& Goldstein, A. P. (1991). Helping people change (Fourth ed.). Boston: Allyn \& Bacon.

Kelchtermans, G., Ballet, K., Peeters, E. \& Verck ens, A. (2007). Good examples of practice as a lever for school development. Leuven: Center for Educational Policy and Innovation.

Lasky, S. (2005). A sociocultural approach to understanding teacher identity, agency and professional vulnerability in a context of secondary school reform. Teaching and Teacher Education, 21(8), 899-916. doi: 10.1016/j.tate.2005.06.003

Lea, M. R., \& Stierer, B. (2011). Changing academic identities in changing academic workplaces: Learning from academics' everyday professional writing practices. Teaching in Higher Education, 16(6), 605-616. doi: 10.1080/13562517.2011.560380

Lotter, Ch., Harwood, W. \& Bonner, J. (2007). The influence of core teaching conceptions on teachers' use of inquiry teaching practices. Journal of Research in Science Teaching, 44(9); 1318-1347. 
McAlpine, L., Weston, C., Berthiaume, D., \& Fairbank-Roch, G. (2006). How do instructors explain their thinking when planning and teaching? Higher Education, 51(1), 125-155. doi: 10.1007/s10734-004-6381-x

Metcalfe, D. H., \& Matharu, M. (1995). Students' perception of good and bad teaching: Report of a critical incident study. Medical Education, 29(3), 193-197. doi: 10.1111/j.1365-2923.1995.tb02829.x

Monereo, C. (2010). ¡Saquen el libro de texto! Resistencia, obstáculos y alternativas en la formación de los docentes para el cambio educativo. Revista de Educación, 352, 583597.

Monereo, C. y Badía, A. (2011) Los heterónimos del docente: Identidad, selfs y enseñanza [Teachers' heteronyms: Identity, self and teaching]. C. Monereo y J. I. Pozo. La Identidad en Psicología de la Educación: necesidad, utilidad y límites. Madrid: Narcea.

Monereo, C. \& Pozo, J.I. (2011). La identidad en psicologia de la educación [Identity in educational psychology]. In C. Monereo \& J. I. Pozo (Eds.) La identidad en psicologia de la educación. Necesidad, utilidad y límites (pp. 11-26) Madrid: Narcea.

Monereo, C., Badia, A., Bilbao, G., Cerrato, M., \& Weise, C. (2009). Ser un docente estrategico: cuando cambiar la estrategia no basta [Being a strategic teacher: when changing tactics is not enough]. Cultura y Educación, 21(3), 237-256. doi: 10.1174/113564009789052343.

Monereo, C., Panadero, E., \& Scartezini, R. (2013). SharEVents. La utilización de informes compartidos sobre incidentes críticos como medio para la formación docente [SharEVents. Using shared reports about critical incidents for teacher development]. Cadernos de Educaçao, 42(2), 45-67.

Muis, K. R. (2007). The role of epistemic beliefs in self-regulated learning. Educational Psychologist, 42(3), 173-190.

Muis, K. R., \& Franco, G. M. (2009). Epistemic beliefs: Setting the standards for selfregulated learning. Contemporary Educational Psychology, 34(4), 306-318. doi: 10.1016/j.cedpsych.2009.06.005

Pintrich, P. R., Marx, R. W., \& Boyle, R. A. (1993). Beyond cold conceptual change: The role of motivational beliefs and classroom contextual factors in the process of conceptual change. Review of Educational Research, 63(2), 167-199. 
Pozo, I. (2006). Nuevas formas de pensar la enseñanza y el aprendizaje : las concepciones de profesores y alumnos [New ways of conceptualizing teaching and learning: teachers' and students' conceptions]. Graó: Spain.

Shapira-Lishchinsky, O. (2011). Teachers' critical incidents: Ethical dilemmas in teaching practice. Teaching and Teacher Education, 27(3), 648-656. doi: 10.1016/j.tate.2010.11.003

Sutton, R., \& Wheatley, K. (2003). Teachers' emotions and teaching: A review of the literature and directions for future research. Educational Psychology Review, 15(4), 327-358. doi: 10.1023/a:1026131715856

Tripp, D. (1993). Critical Incidents in Teaching: Developing Professional Judgement. London: Routledge.

Van Petegem, P., \& Donche, V. (2006). Learning environment research in higher education: assessing constructivist approaches to learning, teaching and learning to teach. In Darell L. Fisher \& Myint Swe Khine (Eds.) Contemporary Approaches to research on learning environments: World views (pp. 93-124), Singapore: World Scientific Publishing.

Van Veen, K., \& Sleegers, P. (2009). Teachers emotions in a context of reforms: To a deeper understanding of teachers and reforms. In P. A. Schutz \& M. Zembylas (Eds.) Advances in teacher emotion research (pp. 233-251). Springer, New York.

Weise, C. (2011). La atención a contextos de alta diversidad sociocultural: un análisis de la identidad y de la práctica docente a través de incidentes críticos [Intervening in high sociocultural diversity contexts: an analysis of teachers' identity and praxis through critical incidents]. Doctoral dissertation. Departamento de Psicología Básica, Evolutiva y de la Educación, Universidad Autónoma de Barcelona, Bellaterra, 2011.

Wudy, D. T., \& Jerusalem, M. (2011). Changes in teachers' self-efficacy and experiences of stress. Psychologie in Erziehung und Unterricht, 58(4), 254-267. doi: 10.2378/peu2011.art16d 